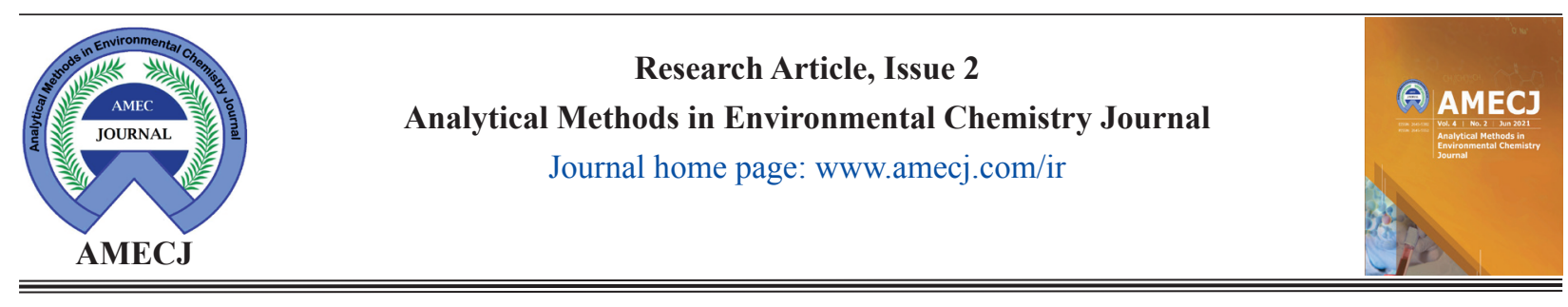

\title{
Ionic liquid functionlized on multiwall carbon nanotubes for nickel and lead determination in human serum and urine samples by micro solid-phase extraction
}

\author{
Arezou Laria ${ }^{a}$ Nafiseh Esmaeili ${ }^{b, *}$ and Homanaz Ghafaric \\ asystems Biomedicine Department, Pasteur Institute of Iran, Tehran, Iran. \\ ${ }^{b}$ Department of chemistry, Faculty of Science, Semnan University, Semnan, Iran \\ ${ }^{\mathrm{c}}$ Department of pharmacology, school of medicine, Tehran university of medical sciences, P.O.Box 784-13145, Tehran,Iran
}

\section{A R T I C L E I N F O :}

Received 11 Mar 2021

Revised form 15 May 2021

Accepted 4 Jun 2021

Available online 30 Jun 2021

Keywords:

Nickel and lead,

Human samples,

Ionic liquid,

Multiwall carbon nanotubes,

Micro solid-phase extraction

\begin{abstract}
A B S T R A C T
In this study, a novel synthesis adsorbent, 1-(3-aminopropyl)-3methylimidazolium hexafluorophosphate functionlized on multiwall carbon nanotubes ([Apmim][PF $]$-MWCNTs, IL@MWCNTS) was used for nickel/lead $(\mathrm{Ni} / \mathrm{Pb})$ extraction and determination by dispersive ionic liquid micro solid-phase extraction (DIL- $\mu$-SPE) coupled to electrothermal atomic absorption spectrometry (ET-AAS). After dilution of $20 \mathrm{mg}$ of IL@MWCNTS in $200 \mu \mathrm{L}$ of acetone, the mixture was injected to $10 \mathrm{~mL}$ of human serum/urine samples at $\mathrm{pH}$ of 8.0. After sonication for $5 \mathrm{~min}$, the $\mathrm{Ni}$ (II) / $\mathrm{Pb}$ (II) were extracted by ionic liquid phase and then centrifuged for $2.5 \mathrm{~min}$. The upper liquid phase set aside and $\mathrm{Ni}(\mathrm{II}) / \mathrm{Pb}$ (II) loaded in adsorbent were backextracted by acidic solution at $\mathrm{pH}=2-3$. Finally, the concentration of total nickel and lead was determined by ET-AAS. By optimizing, the limit of detection, linear range, and enrichment factor for nickel and lead were obtained $\left(0.05 \mu \mathrm{g} \mathrm{L}^{-1} ; 0.1 \mu \mathrm{g} \mathrm{L}{ }^{-1}\right),\left(0.2-5.8 \mu \mathrm{g} \mathrm{L}^{-1} ; 0.4-\right.$ $30 \mu \mathrm{g} \mathrm{L}^{-1}$ ) and $24.7 ; 5.1$, respectively (RSD less than $5 \%$ ). Also, the capacity absorption of IL@MWCNTS for nickel and lead ions were achieved $149.3 \mathrm{mg} \mathrm{g}^{-1}$ and $162.5 \mathrm{mg} \mathrm{g}^{-1}$, respectively. The DIL- $\mu$-SPE procedure was validated for nickel and lead extraction by spiking of real samples and ICP-MS analyzer.
\end{abstract}

\section{Introduction}

Lead and nickel $(\mathrm{Pb}, \mathrm{Ni})$ have toxic effects and use in different industries. Heavy metals as nonessential elements have widely distributed in the environment (air, soils, waters) and humans. Human exposure of heavy metals cause to various diseases such as cancer. $\mathrm{Pb}$ and $\mathrm{Ni}$ is a naturally occurring element found in small amounts in the earth's crust [1]. While it has some beneficial uses, it can be toxic to humans and animals, and cause to health effects.

\footnotetext{
*Corresponding Author: Nafiseh Esmaeili

Email: esmaeilin@gmail.com, esmaeilin@semnana.ac.ir https://doi.org/10.24200/amecj.v4.i02.144
}

The most exposure of lead and nickel related to human activities including, the fossil fuels, gasoline, the industrial facilities, the nickel cadmium battery, and paint factories. Lead and nickel compounds have been used in a wide variety of products found in different industries, including paint, ceramics, pipes and plumbing materials, gasoline, batteries, and cosmetics $[2,3]$. High levels of human exposure to $\mathrm{Ni}$ and $\mathrm{Pb}$ metals cause to damage the most of human organ systems such as, the central nervous system (CNS), kidneys, liver, bones and gastrointestinal system. Lead can also effect on hemoglobin synthesis and cause to anemia effects or accumulate in the bones. Depending on the level of exposure, 
the lead and nickel can adversely effect on the nervous system, immune system, reproductive and the cardiovascular system [4-7]. Infants and young children are especially sensitive to lead exposures, which may contribute to behavioral problems, learning deficits and lowered IQ [8]. Lead can also be emitted into the environment from industrial sources and contaminated sites, such as former lead smelters. While natural levels of lead in soil range between 50 and 400 parts per million, mining, smelting and refining activities have resulted in substantial increases the lead levels in the environment, especially near mining and smelting sites. Lead can be added to soils and sediments through deposition from sources of lead by air pollution. Lead can be added to proteins and amino acids which was caused neurological problems $[9,10]$. Due to the environmental protection agency (EPA), the maximum contaminant level (MCL) for $\mathrm{Pb}$ in waters is zero and has no effect in humans [2]. Also, the National toxicology program (NTP) announced that the lead concentration in blood and serum must be less than $50 \mu \mathrm{g} \mathrm{L}^{-1}$ in children. The variable lead values in human blood/serum was about $250-300 \mu \mathrm{g} \mathrm{L}^{-1}$ which was reported by food and drug administration (FDA) [11]. As references, the standard blood lead levels are below $25 \mathrm{mg} \mathrm{dL}^{-1}$ or 250 microgram per liter. The permissible exposure level in the ambient (air, water, soil, etc.) environment has been reported [12-14]. Nickel (Ni) caused to acute disease in humans [15]. Ni(II) can be enter to waters from waste water of different industries such as battery and electroplating factories [16]. Nickel complex to various proteins and enzyme in the human body. Nickel toxicity caused to many problems in human systems or organs such as renal, liver, brain, cardiovascular system, immune system and heart. The symptoms diseases included lung dysfunction and cancer was seen for nickel exposure [17]. Oral values for rats range from $67-9000 \mathrm{mg} \mathrm{Ni}$ per kg (ATSDR). Toxic effects of oral exposure to nickel usually involve the kidneys (ATSDR). Normal range for $\mathrm{Ni}$ in healthy peoples is $0.2 \mu \mathrm{gL}^{-1}$ in serum and less than $3.0 \mu \mathrm{gL}^{-1}$ in human urine.
$[18,19]$. Nickel (II) in urine and serum samples determined with UV-VIS spectrophotometry and flame atomic absorption spectrometry techniques [20]. Recently, the various techniques such as, the inductively coupled plasma(ICP), the inductively coupled plasma mass spectrometry(ICP-MS) [21], the flame atomic absorption spectrometry F-AAS [22], the X-ray fluorescence spectrometry [23] and the electrothermal atomic absorption spectrometry (ET-AAS) were used to determine $\mathrm{Ni}$ and $\mathrm{Pb}$ ions in different matrixes [24]. Due to ultra-trace concentration of $\mathrm{Pb}$ and $\mathrm{Ni}$ in human samples (urine and serum) and difficulty matrices in human biological samples, the sample treatment was used. For Examples, the solid phase extraction(SPE) [25], the magnetic dispersive micro-solid phase extraction (MD- $\mu$-SPE) [26,27], the dispersive micro solid phase microextraction (D-SPME) [28], the needle hub in-syringe solid phase extraction (NHS-SPE) [29], and liquid-liquid microextraction (LLME) [30, 31] were used. Among them, the dispersive micro solidphase extraction D- $\mu$-SPE was mostly used for determination of heavy metals such as $\mathrm{Ni}$ and $\mathrm{Pb}$ in water and humans. Task ionic liquids were used for extraction of heavy metals from liquid phase by $\mathrm{N}, \mathrm{S}$ groups. The D- $\mu$-SPE procedure have advantages such as easy to use, simple, high recovery and efficient extraction. In this process, the adsorbent properties are main factor for heavy metal extraction by D- $\mu$-SPE procedure. The high surface area of nanoparticles caused to increase the extraction recovery and absorption capacity. Recently, the various nanostructures were used for extraction $\mathrm{Pb}$ and $\mathrm{Ni}$ in waters, human urine and serum samples $[32,33]$. In this study a novel ionic liquid ([Apmim] $\left.]\left[\mathrm{PF}_{6}\right]\right)$ functionalized on MWCNTs (IL-MWCNTs) was used for extraction of $\mathrm{Ni}$ and $\mathrm{Pb}$ ions in human urine and serum samples by the DIL- $\mu$-SPE procedure. The $\mathrm{Ni}$ and $\mathrm{Pb}$ concentration was determined by the ET-AAS after sample preparation. The main parameters on lead and nickel extraction were studied and evaluated. 
Table 1. The ET-AAS conditions for lead and nickel determination.

\begin{tabular}{lll}
\hline Features & Value $\mathbf{P b}$ & Value Ni \\
\hline Linear range, $\mu \mathrm{g} \mathrm{L} \mathbf{b}^{-1}$ & $3-90$ & $5-85$ \\
Working range, $\mu \mathrm{g} \mathrm{L}^{-1}$ & $3-150$ & $5-145$ \\
Wavelength, nm & $283.3,217.0$ & 232.0 \\
Lamp current, $\mathrm{mA}$ & 5.0 & 4.0 \\
Slit, nm & 0.5 & 0.2 \\
Mode & Peak Area & Peak Area \\
Auto Sampler $(\mu \mathrm{L})$ & $1-100$ & $1-100$ \\
LOD & 0.75 & 1.25 \\
LLOQ & 3.0 & 5.0 \\
$\mathrm{R}^{2}$ & 0.9998 & 0.9997 \\
\hline
\end{tabular}

\section{Materials and Methods}

\subsection{Apparatus}

The AAS (GBC, 932, AUS) based on furnace accessory (Pal 3000) and deuterium $\left(\mathrm{D}_{2}\right)$ /hollow-cathode lamp $(\mathrm{Ni}, \mathrm{Pb})$ was used. The sample was transferred to $2 \mathrm{~mL}$ of PVC tube in Pal3000 as auto-sampler accessory. The conditions of ET-AAS were shown in Table 1. The lead determination was achieved by injecting $20 \mu \mathrm{L}$ of sample to graphite tube with auto-sampler in three steps of drying, ashing, and atomization. The ICP-MS (PerkinElmer, USA) was used for ultra-trace $\mathrm{Ni}$ and $\mathrm{Pb}$ analysis in different matrixes. The conditions of ICPMS were tuned for $\mathrm{Ni}$ and $\mathrm{Pb}$ determination in samples $\left(1200 \mathrm{~W}, 12 \mathrm{~L} \mathrm{~min}^{-1}\right.$ per $\left.1 \mathrm{~s}\right)$. The auxiliary gas flow was adjusted $1.2 \mathrm{~L} \mathrm{~min}^{-1}$. The quantitative analysis of lead and nickel were obtained in PPT concentration by ICP-MS analyzer $(<10 \mathrm{ppt})$. The range of $\mathrm{pH}$ values of the serum and urine samples were measured by $\mathrm{pH}$ meter (Metrohm) and adjusted by favorite buffer solution. The shaker accessory (USA, Domingo Lab) by stirring speed between 10 210 PRM and working platform of $315 \times 218 \mathrm{~mm}(12.5$ " $\times 8.5$ ") with voltage $220 \mathrm{~V}$ was used. The Eppendorf centrifuge offers 24 place capacity in an aerosol-tight rotor and speeds up to $21,300 \times \mathrm{g}$ was used (Laboratory centrifuge model 5418 R, Eppendorf, Germany). was used by the DIL- $\mu$ -
SPE procedure. The polypropylene syringe and conical tube were purchased from Sigma (Germany). Fourier transform infrared (FT-IR) spectra were obtained by a Perkin Elmer Spectrum (65 FT-IR). X-ray diffraction (XRD) was reported by a X'Pert PRO X-ray diffractometer. Scanning electron microscopy (SEM) images were achieved using a Tescan Mira-3.

\subsection{Reagents}

In this study, the analytical grade of reagents was prepared from Merck / Sigma Aldrich (Germany). The standard solution of lead $\left(\mathrm{Pb}^{2+}\right)$ was purchased from Merck CO. (Germany) with a concentration of 1000 $\mathrm{mg} \mathrm{L}^{-1}$ in $1 \% \mathrm{HNO}_{3}$. The standard stock solutions (1000 $\left.\mathrm{mg} \mathrm{L}^{-1}\right)$ of Ni (II), were purchased from Merck (Darmstadt, Germany). Another concentration of lead and nickel was daily prepared by dilution of the standard lead solution with DW. Ultrapure water was purchased from Millipore Company (Bedford, USA) for dilution of solutions or standards. The $\mathrm{pH}$ was adjusted by sodium phosphate buffer solution for $\mathrm{pH}$ 5.7-8.2. The reagents such as acetonitrile (CAS N.: 75-05-08, Merck), polyoxyethylene octyl phenyl ether (TX-100, CAS N: 9002-93-1, Sigma, Germany), and toluene (CAS N: 108-88-3, Merck), $\mathrm{HNO}_{3}$, xylene, $\mathrm{HCl}$, ethanol, and acetone, were prepared from Merck, 
Germany. MWCNTs adsorbent prepared from RIPI company in Iran. aminoopropyltrimethoxysilane (APTMS) was prepared from Sigma, Germany.

\subsection{Synthesis of [Apmim][PF $]-M W C N T$ S}

The carboxylic acid of MWCNTs was prepared by the acid treatment procedure according to previous reports [34]. Then, the carboxylic acid (COOH) on MWCNTs was treated with $\mathrm{NaBH}_{4} / \mathrm{CH}_{3} \mathrm{OH}$, and $\mathrm{COOH}$ were reduced to $\mathrm{CH}_{2} \mathrm{OH}$ groups. Typically, in a $100 \mathrm{~mL}$ flask / condenser / magnetic stirrer (MSB), the sodium borohydride $(0.5 \mathrm{~g})$ added to $5 \mathrm{~g}$ of MWCNTs- $\mathrm{COOH}$ and in presence of methanol refluxed / cooled/ filtered / washed with methanol. Then $2.0 \mathrm{~g}$ of MWCNTs $\mathrm{OH}$ were added to 3-aminoopropyltrimethoxysilane (APTMS) in xylene $(50 \mathrm{ml})$ and heated. Then, the product was filtered, washed with ethanol. Finally, Immobilization of the carbonyl group on the MWCNTs was accomplished by stirring the aminopropylfunctionalized CNTs in an ethanolic solution of terephthalaldehyde $(0.5 \mathrm{~g})$ for $3 \mathrm{~h}$ at $70{ }^{\circ} \mathrm{C}$. An ethanolic solution carbonyl-functionalized MWCNTs were moved to ultrasonic bath for 15 minutes. After the sonication, a solution of $[\mathrm{Apmim}]\left[\mathrm{PF}_{6}\right] \mathrm{in} \mathrm{EtOH}$ $(10 \mathrm{~mL})$ was added dropwise to mentioned suspension during $10 \mathrm{~min}$ at $80^{\circ} \mathrm{C}$. The reaction mixture was refluxed for $4 \mathrm{~h}$ at $80^{\circ} \mathrm{C}$ by $\mathrm{N}_{2}[34]$.

\subsection{General procedure}

By the DIL- $\mu$-SPE procedure, $10 \mathrm{~mL}$ of human urine and serum sample was used for extraction $\mathrm{Pb}$ and $\mathrm{Ni}$ by IL-MWCNTs. Firstly, $10 \mathrm{~mL}$ of human samples and standard solution containing $0.2 \mu \mathrm{g} \mathrm{L}^{-1} ; 0.4 \mu \mathrm{g} \mathrm{L}^{-1}$ (lower limit) and $5.5 \mu \mathrm{g} \mathrm{L}^{-1} ; 30 \mu \mathrm{g} \mathrm{L}-1$ (upper limit) for $\mathrm{Ni}$ and $\mathrm{Pb}$ was used, respectively at $\mathrm{pH}$ of 8.0. Then, 20 mg of IL-MWCNTs mixed with $0.2 \mathrm{~mL}$ of acetone and injected to $10 \mathrm{~mL}$ samples /standard solution in PVC centrifuge conical tube. The mixture was shaken for 6 min and $\mathrm{Pb} / \mathrm{Ni}$ ions were extracted by amine group of $[$ Apmim $]\left[\mathrm{PF}_{6}\right]$ at optimized $\mathrm{pH}$. Then, the adsorbent was collected from liquid phase by centrifuging of samples. Then, the Ni loaded on adsorbent was back extracted with $0.2 \mathrm{~mL}$ of nitric acid $(0.3 \mathrm{M})$ and diluted with $0.2 \mathrm{~mL}$ of DW. Also, the lead loaded on adsorbent was back extracted with $0.2 \mathrm{~mL}$ of nitric acid $(0.3 \mathrm{M})$ and diluted with DW up $2 \mathrm{~mL}$. Finally, the solution was determined by ET-AAS (Fig.1, Table 2). The recovery of extraction with IL-MWCNTs adsorbent was obtained for $\mathrm{Pb} / \mathrm{Ni}$ concentration by the equation 1. The $C_{A}$ is the primary concentrations and $C_{S}$ is the secondary concentration of $\mathrm{Pb}(\mathrm{II}) / \mathrm{Ni}(\mathrm{II})$, which was determined by ET-AAS ( $\mathrm{n}=10$, Eq. 1).

$$
\text { Recovery\% }=\left(\mathrm{C}_{\mathrm{A}}-\mathrm{C}_{\mathrm{S}}\right) / \mathrm{C}_{\mathrm{A}} \times 100 \quad(\text { Eq. } 1)
$$

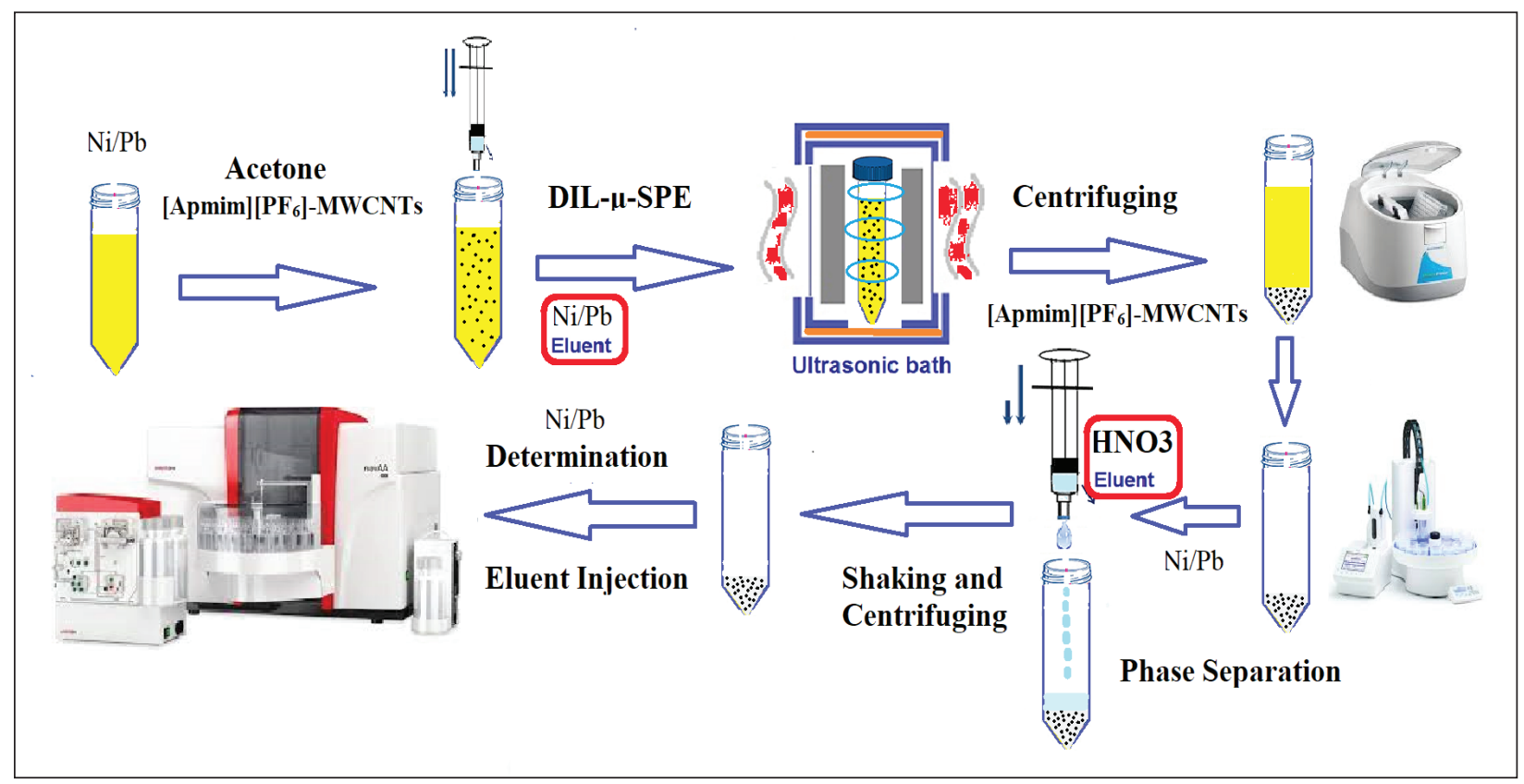

Fig. 1. The DIL- $\mu$-SPE procedure based on IL-MWCNTs for Pb and Ni extraction 
Table 2. The analytical features for determination lead and nickel by DIL- $\mu$-SPE procedure coupled to ET-AAS

\begin{tabular}{lll}
\hline Features & Value Pb & Value Ni \\
\hline Working pH & $7.5-8.5$ & 8.0 \\
Amount of Il-MWCNTs $(\mathrm{mg})$ & 18 & 20 \\
Sample volume of serum $(\mathrm{mL})$ & 10.0 & 10.0 \\
Sample volume of urine, water $(\mathrm{mL})$ & 15.0 & 12.0 \\
Volume of sample injection $(\mu \mathrm{L})$ & 20 & 20 \\
Linear range for serum $\left(\mu \mathrm{g} \mathrm{L}^{-1}\right)$ & $0.4-30$ & $0.2-5.8$ \\
Mean RSD \%, $\mathrm{n}=10$ & 4.2 & 3.9 \\
LOD for urine or serum $\left(\mu \mathrm{g} \mathrm{L}^{-1}\right)$ & 0.1 & 0.05 \\
Enrichment factor for urine or serum & 5.1 & 24.7 \\
Volume and concentration of $\mathrm{HNO}_{3}$ & $0.2 \mathrm{~mL}, 0.3 \mathrm{M}$ & $0.2 \mathrm{~mL}, 0.2 \mathrm{M}$ \\
Shaking/Centrifuging time & $6.0 \mathrm{~min}, 4.0 \mathrm{~min}$ & $6.0 \mathrm{~min}, 4.0 \mathrm{~min}$ \\
Correlation coefficient & $\mathrm{R}^{2}=0.9997$ & $\mathrm{R}^{2}=0.9995$ \\
\hline
\end{tabular}

\section{Results and discussion}

The lead and nickel were extracted and determined based on the IL-MWCNTs nanostructures which characterized by scanning electron microscopy (SEM), X-ray diffraction spectroscopy (XRD), and Fourier transform infrared spectroscopy (FT-IR).

\subsection{X-ray diffraction spectroscopy (XRD)}

The powder XRD patterns of pristine MWCNTs (a) and $[$ Apmim $]\left[\mathrm{PF}_{6}\right]$ immobilized on MWCNTs (b) are shown in Figure 2. The XRD of the MWCNTs and IL-MWCNTs were compared. The two characteristic graphitic peaks, at a $2 \theta$ value $\left(28^{\circ}\right.$ and $45^{\circ}$ ) corresponding to the peaks of the (002) and (100) planes of hexagonal graphite MWCNT, respectively, are present in the XRD pattern of both measured samples. As shown in Figure 2, after functionalized of [Apmim] $\left[\mathrm{PF}_{6}\right]$ on MWCNTs, no new peaks were seen, and the characteristic peaks of MWCNTs didn't change.

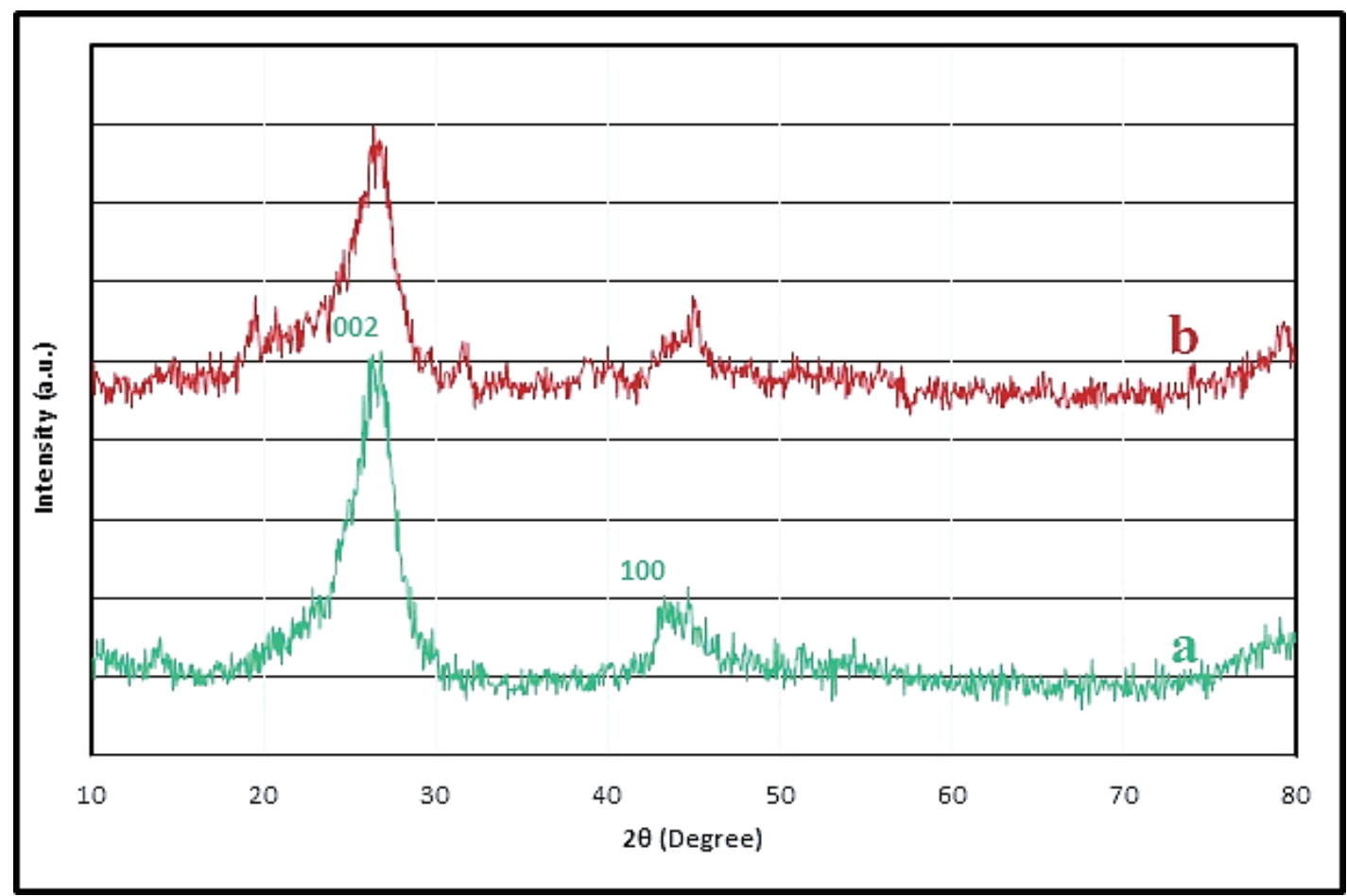

Fig. 2. The XRD of a) MWCNTs and b) IL-MWCNTs 

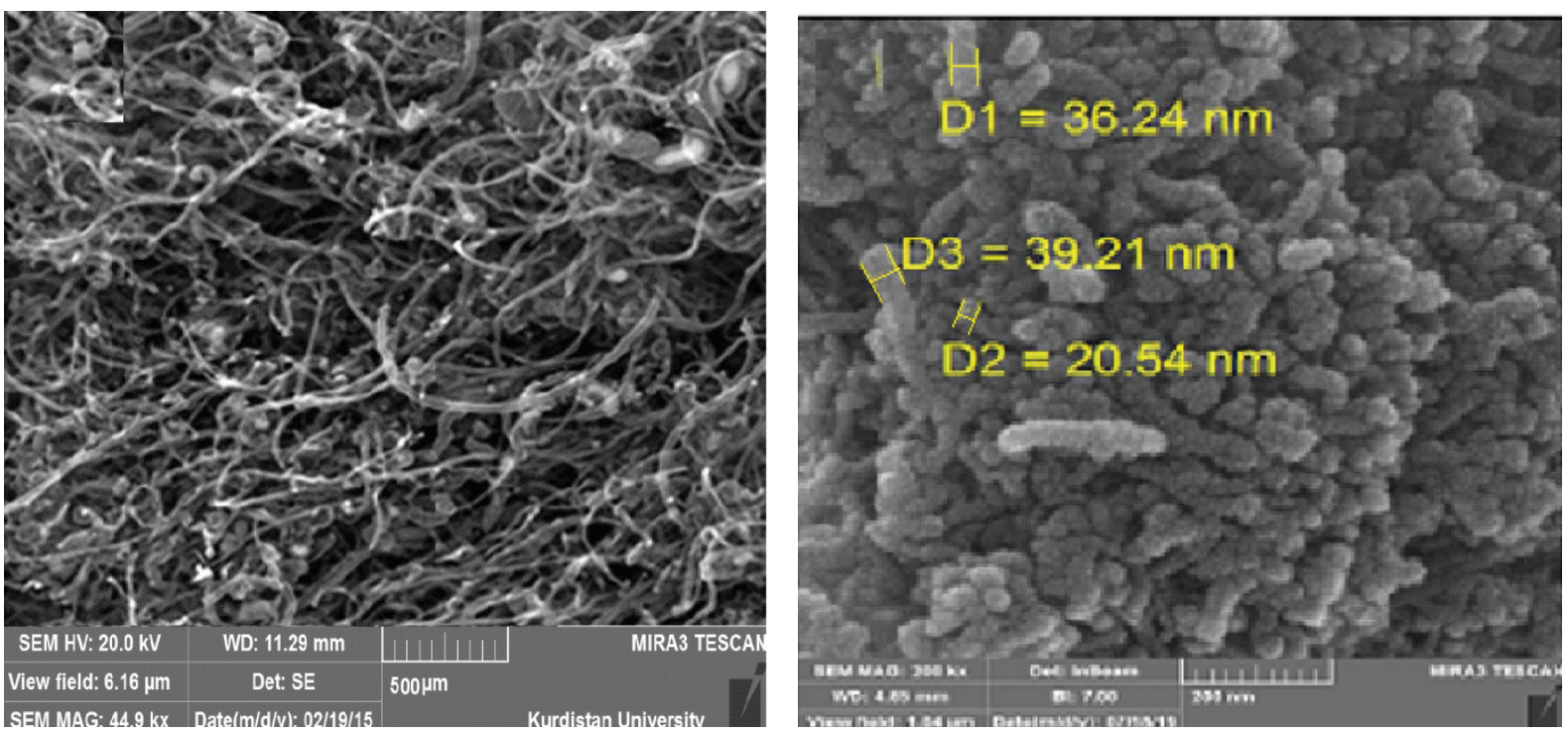

Fig. 3 . FE-SEM images of $[\mathrm{Apmim}]\left[\mathrm{PF}_{6}\right]$ immobilized on MWCNTs

\subsection{Field emission scanning electron microscopy (FE-SEM)}

FE-SEM images of $[$ Apmim $]\left[\mathrm{PF}_{6}\right]$ immobilized on MWCNTs are shown in Figure 3. It showed that the nanotubes have previous form and save their nature as MWCNTs. Due to FE-SEM images with different scale bars, a clear change in the morphology of $[\mathrm{Apmim}]\left[\mathrm{PF}_{6}\right]$ immobilized on MWCNTs were seen that showed the ionic liquid has been immobilized on the MWCNTs. The FESEM showed that, the IL-MWCNTs have nano size between $20-60 \mathrm{~nm}$.

\subsection{Fourier transform infrared spectroscopy (FT-IR)}

The FT-IR spectra of $\left[\right.$ Apmim] $\left[\mathrm{PF}_{6}\right]-\mathrm{MWCNTs}$ are shown in Figure 4. This FTIR spectrum showed that the oxidation and covalently bond of the pristine MWCNTs. The peak of $1717 \mathrm{~cm}^{-1}$ is showed to the carbonyl bond (CO) due to oxidation functionalities. Also, the peak at $3437-3439 \mathrm{~cm}^{-1}$ was assigned to the stretching of $\mathrm{O}-\mathrm{H}$ groups on the inner surface of oxidized MWCNTs. The supporting of the aminopropylsilane group on $\mathrm{OH}$ by treatment with APTMS was confirmed by the appearance of a sharp peak at around $1094 \mathrm{~cm}^{-1}$ which is attributed to the O-Si-O bond constructed between MWCNTs and ionic liquid moieties. The IR peak at 2922 and $2854 \mathrm{~cm}^{-1}$ were related to asymmetric and symmetric vibration absorptions, respectively, for the aliphatic $\mathrm{CH}_{2}$ groups $(\mathrm{C}-\mathrm{H})$ of chlorosilane coupling agent and butyl chain of [Apmim] $\left[\mathrm{PF}_{6}\right]$.

\subsection{Optimization of DIL- $\mu$-SPE procedure}

The DIL- $\mu$-SPE procedure was used based on ILMWCNTs as a new adsorbent for determination lead and nickel in human urine and serum samples. High efficient recoveries, low RSD / LOD and variable linear ranges were obtained by optimizing of parameters such as, $\mathrm{pH}$, amount of IL-MWCNTs, $\mathrm{HNO}_{3}$ volume and concentration, the urine/ serum volume, and the capacity of adsorption for extraction of $\mathrm{Pb}$ and $\mathrm{Ni}$ ions in human biological samples.

\subsubsection{The pH optimization}

The $\mathrm{pH}$ of urine and serum sample has a main role for adsorption of lead and nickel ions on IL-MWCNTs by DIL- $\mu$-SPE procedure. The effect of $\mathrm{pH}$ range on the extraction of $\mathrm{Pb}$ and $\mathrm{Ni}$ with adsorbent was studied for $\mathrm{Ni}$ and $\mathrm{Pb}$ concentration between 0.2-5.5 $\mu \mathrm{g} \mathrm{L}^{-1}$ and 0.4-30 $\mu \mathrm{g} \mathrm{L}^{-1}$, respectively (Fig. 5). Based on results, the recovery for $\mathrm{Ni}$ (II) and $\mathrm{Pb}$ (II) ions were increased at $\mathrm{pH}$ range of 8.0 more than $96 \%$. Also, the extraction recoveries decreased at $\mathrm{pH}$ more than 8.5 and less than 7. So, the $\mathrm{pH}$ of 8 was selected 


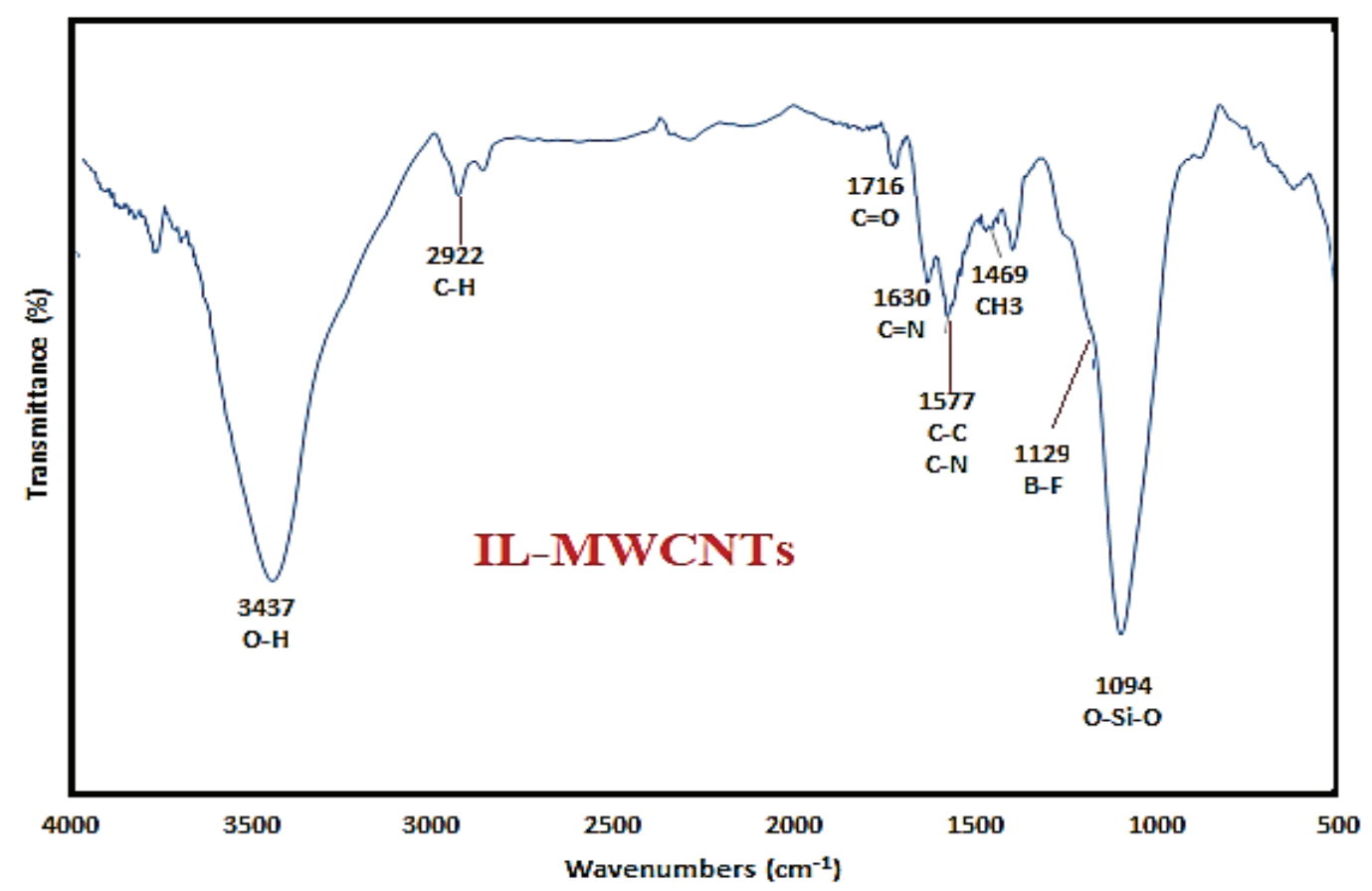

Fig.4. The FT-IR spectra of IL-MWCNTs

as optimal $\mathrm{pH}$ by the DIL- $\mu$-SPE procedure. The adsorption mechanism on the IL-MWCNTs was achieved based on deprotonated amine groups $\left(\mathrm{Pb}^{2+} / \mathrm{Ni}^{2+} \rightarrow \mathrm{M} . . . .-\mathrm{NH}_{2}-\mathrm{IL}\right)$ with the positively charged of metals in optimized $\mathrm{pH}$. At lower $\mathrm{pH}$, the surface of IL-MWCNTs have positively charged due to the $\mathrm{H}^{+}$protonation. Therefore, the extraction efficiencies were reduced by the similar charge law between $\mathrm{Pb}^{2+} / \mathrm{Ni}^{2+a n d}$ positively charged of ${ }^{+} \mathrm{NH}_{2}$ of IL. Moreover, at $\mathrm{pH}$ of 8.0 , the $\mathrm{NH}_{2}$ group of IL had negative charge (-) and caused to increase adsorption adsorbent. The results showed, high recovery for extraction $\mathrm{Pb} / \mathrm{Ni}$ were achieved at $\mathrm{pH}=8$. In addition, the extraction efficiency was obtained about $30 \%$ in low pH as physically adsorption.

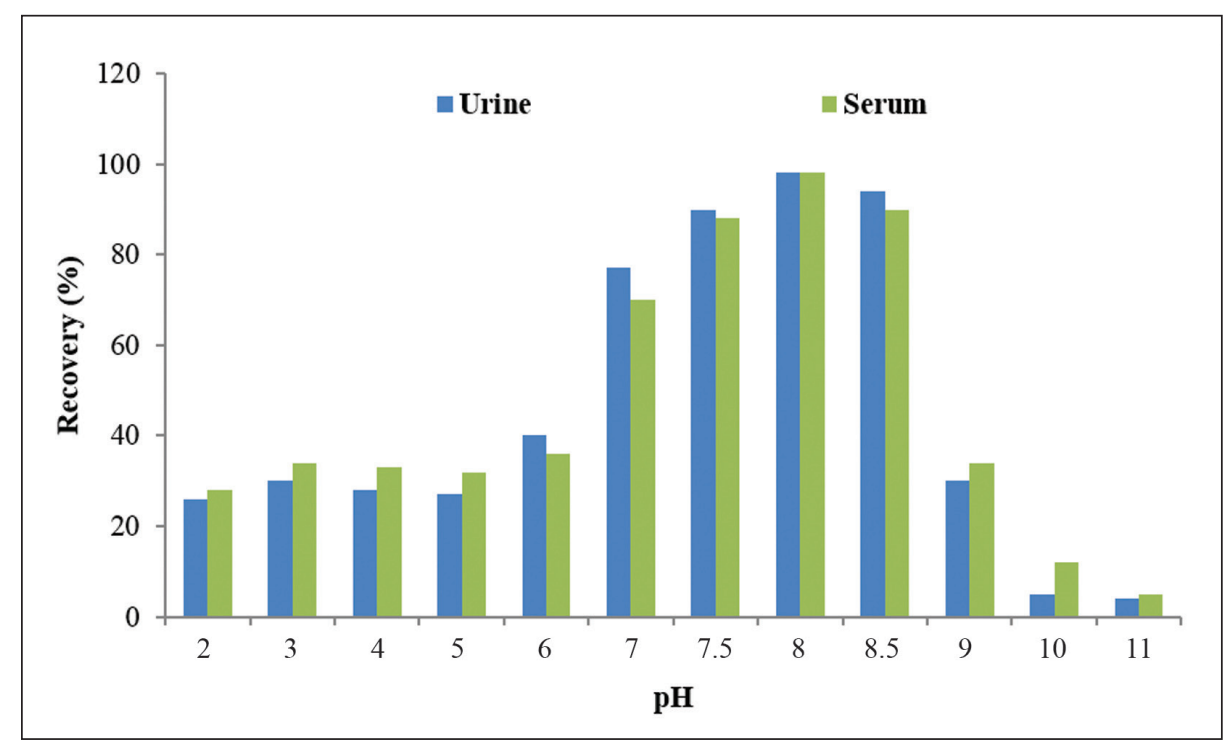

Fig. 5. The effect of $\mathrm{pH}$ on $\mathrm{Pb} / \mathrm{Ni}$ extraction by the $\mathrm{DIL}-\mu-\mathrm{SPE}$ procedure 


\subsubsection{Optimization of amount of IL-MWCNTS}

By the DIL- $\mu$-SPE procedure, the amount of ILMWCNTs was optimized for extraction of $\mathrm{Ni}(\mathrm{II})$ and $\mathrm{Pb}(\mathrm{II})$ in urine and serum samples. In this study, the amount of 5-40 mg of IL-MWCNTs was studied. The results showed that the $18 \mathrm{mg}$ of ILMWCNTs had high extraction for Ni(II) and $\mathrm{Pb}(\mathrm{II})$ in urine and serum samples in optimized conditions. Therefore, $20 \mathrm{mg}$ of IL-MWCNTs was selected as optimal amount of IL-MWCNTs (Fig. 6). The more amount of IL-MWCNTs had no effect on the extraction recovery of $\mathrm{Pb} / \mathrm{Ni}$ at $\mathrm{pH}=8$.

\subsubsection{Effect of eluent}

The volume and concentration of eluents for lead and nickel extraction in urine and serum samples was studied. By the DIL- $\mu$-SPE procedure, the various mineral acids were selected as elution phase for back extraction $\mathrm{Pb}$ (II) and $\mathrm{Ni}$ (II) from ILMWCNTs phase at low $\mathrm{pH}$. At low $\mathrm{pH}$, the covalent bond between metal and amine group break down and $\mathrm{Ni} / \mathrm{Pb}$ ions release in liquid phase. The different volumes from 100 to $500 \mu \mathrm{L}$ and concentration between 0.1-0.5 $\mathrm{mol} \mathrm{L}^{-1}$ were used as eluent phase ( $\mathrm{HCl}, \mathrm{HNO}_{3}, \mathrm{H}_{2} \mathrm{SO}_{4}$ and $\mathrm{H}_{3} \mathrm{PO}_{4}$ ) by the DIL- $\mu$-SPE method. The results showed that the $0.2 \mathrm{~mol} \mathrm{~L}^{-1}$ of $\mathrm{HNO}_{3}(0.2 \mathrm{~mL})$ had quantitatively back extracted $\mathrm{Pb} / \mathrm{Ni}$ ions from IL-MWCNTs (Figs. 7). So, the $\mathrm{HNO}_{3}$ was used for further works.

\subsubsection{Sample volume optimization}

The sample volume affected on the recoveries of $\mathrm{Pb}$ (II) and $\mathrm{Ni}$ (II) ions at $\mathrm{pH}=8$. In this research, the various sample volumes of urine and serum from 1 to $20 \mathrm{~mL}$ were studied for $\mathrm{Pb}$ (II) and $\mathrm{Ni}$ (II) extraction in presence of the concentration between 0.2-5.5 $\mu \mathrm{g} \mathrm{L}^{-1}$ and $0.4-30 \mu \mathrm{g} \mathrm{L}^{-1}$ for nickel and lead, respectively by the DIL- $\mu$-SPE procedure. The results showed, the high extraction recoveries less than $12 \mathrm{~mL}$ and $15 \mathrm{~mL}$ for lead and nickel in urine samples were obtained, respectively. Also, the good recoveries less than $10 \mathrm{~mL}$ for lead and nickel in serum samples was achieved. Moreover, the extraction efficiency $\mathrm{Pb}$ (II) and $\mathrm{Ni}$ (II) ions was reduced by increasing more than $10 \mathrm{~mL}$ samples.
Therefore, $10 \mathrm{~mL}$ was used as the optimal sample volume by proposed procedure (Fig. 8).

\subsubsection{Time of extraction}

The interaction of IL-MWCNTs with $\mathrm{Pb}$ (II) and $\mathrm{Ni}$ (II) ions is main factor for extraction process by DIL- $\mu$-SPE procedure. So, the time dispersion of the IL-MWCNTs for metal extraction in the urine and serum samples were calculated. The high interaction caused to increase the extraction of metals in liquid phase. The effect of the ultrasonic time was evaluated based on IL-MWCNTs adsorbent at $\mathrm{PH}=8$. The results showed, the maximum recovery was obtained about $6.0 \mathrm{~min}$.

\subsection{Reusability and Adsorption capacity}

The reusability of IL-MWCNTs for extraction of with $\mathrm{Pb}$ (II) and $\mathrm{Ni}$ (II) ions was examined for several analyses by the DIL- $\mu$-SPE method. The good recovery based on 19 times of extraction and back extraction cycles was obtained for $\mathrm{Pb}(\mathrm{II})$ and Ni(II) by IL-MWCNTs. Also, the absorption capacities IL- MWCNTs and MWCNTs for Pb(II) and $\mathrm{Ni}(\mathrm{II})$ extraction in urine and serum samples were achieved based on amine group of IL and surface area of MWCNTs. For this propose, 20 mg of IL-MWCNTs and MWCNTs were added to $10 \mathrm{~mL}$ of standard solution with concentration of $10 \mathrm{mg} \mathrm{L}^{-1}$ of $\mathrm{Pb}(\mathrm{II})$ and $\mathrm{Ni}(\mathrm{II})$ in batch system at optimized $\mathrm{pH}$. By results, the adsorption capacity of MWCNTs and IL- MWCNTs for Ni(II) and $\mathrm{Pb}$ (II) was found $21.4 / 26.7 \mathrm{mg} \mathrm{g}^{-1}$ and 149.3 / 162.5 $\mathrm{mg} \mathrm{g}^{-1}$, respectively.

\subsection{The effect of concomitant ions}

The effect of interference ions on $\mathrm{Pb}$ (II) and $\mathrm{Ni}$ (II) extraction was studied in human urine and serum samples by DIL- $\mu$-SPE procedure (Table 3). In optimized conditions, the various interfering ions in human biological samples was added to $10 \mathrm{~mL}$ of $\mathrm{Pb}$ (II) and $\mathrm{Ni}$ (II) of standard solution with concentration of $30 \mu \mathrm{g} \mathrm{L}^{-1}$ and 5.5 $\mu \mathrm{g} \mathrm{L}^{-1}$, respectively. The results showed, the main concomitant ions had no effect on the metal extraction at $\mathrm{pH}=8$. The IL-MWCNTs had good 


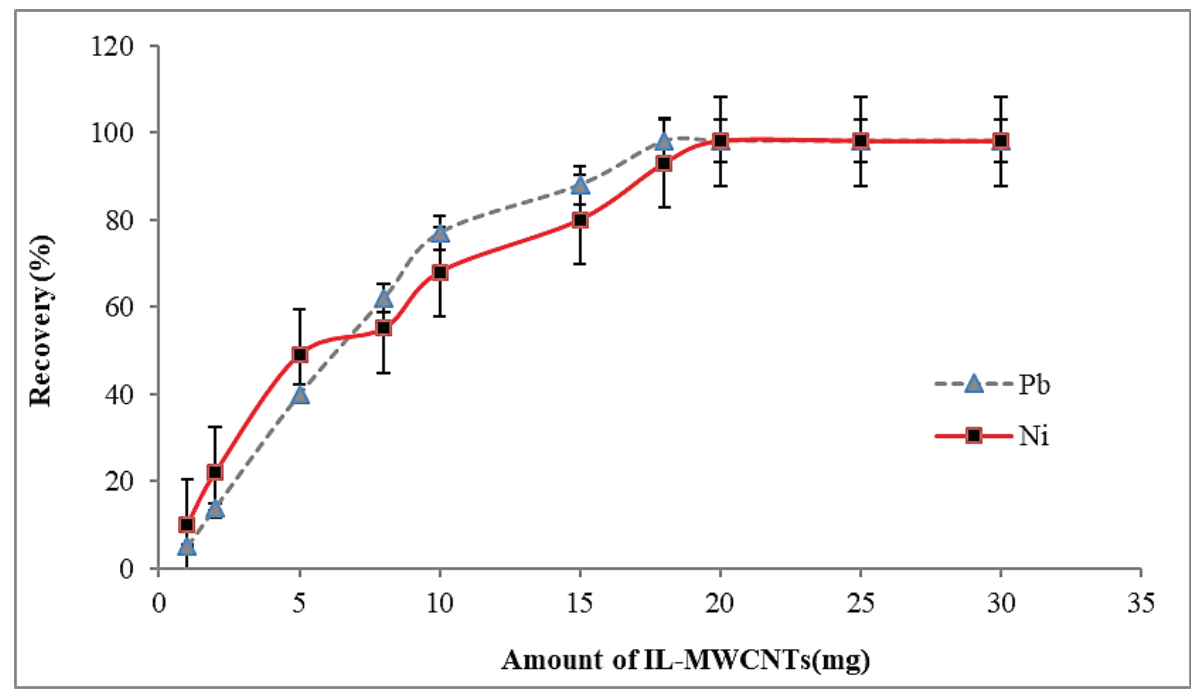

Fig. 6. The effect of amount of Il-MWCNTs on Pb/Ni extraction by the DIL- $\mu$-SPE procedure
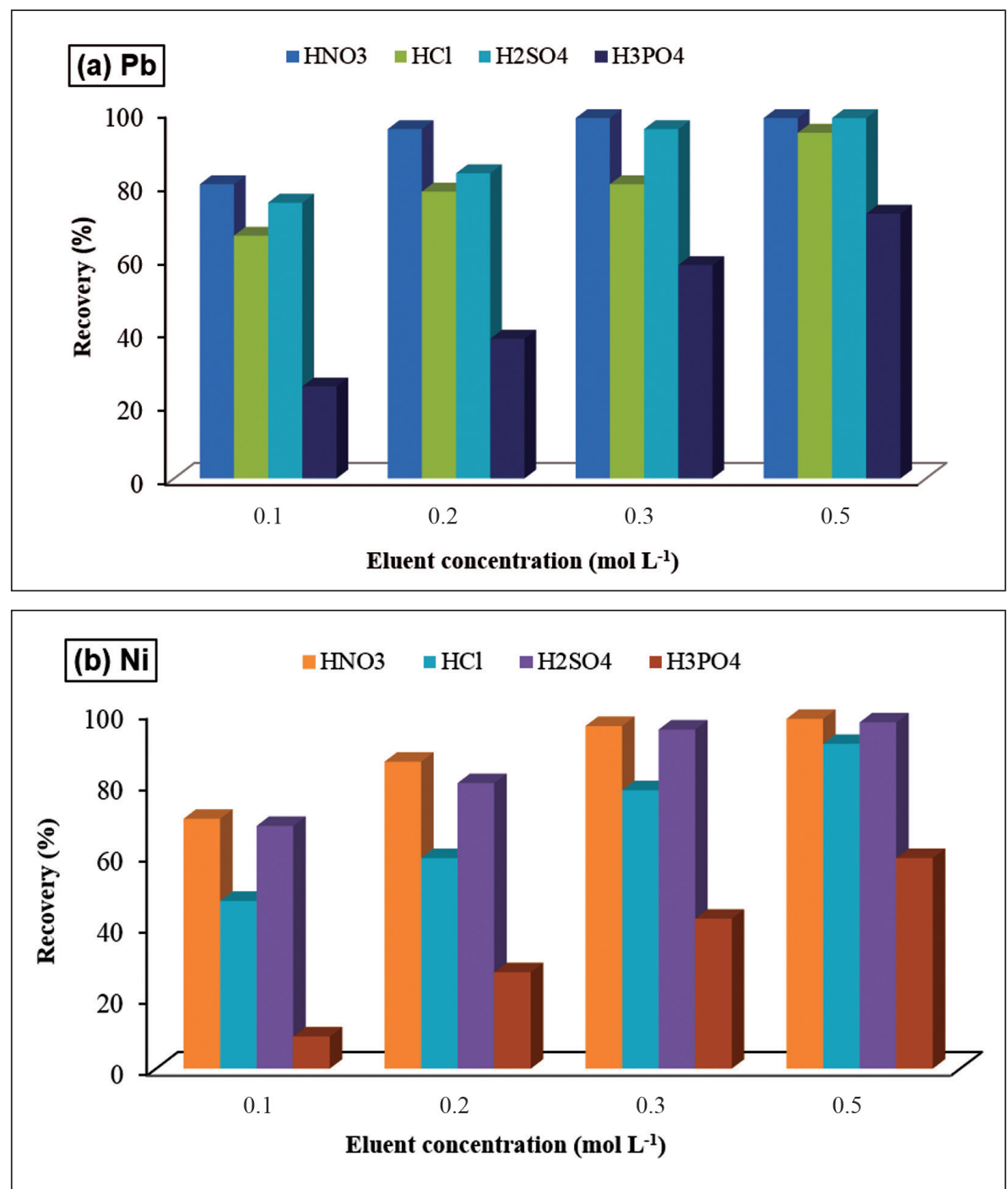

Fig. 7. The effect of eluent for back-extraction of a) lead and b) nickel from ILMWCNTs by the DIL- $\mu-$ SPE procedure 


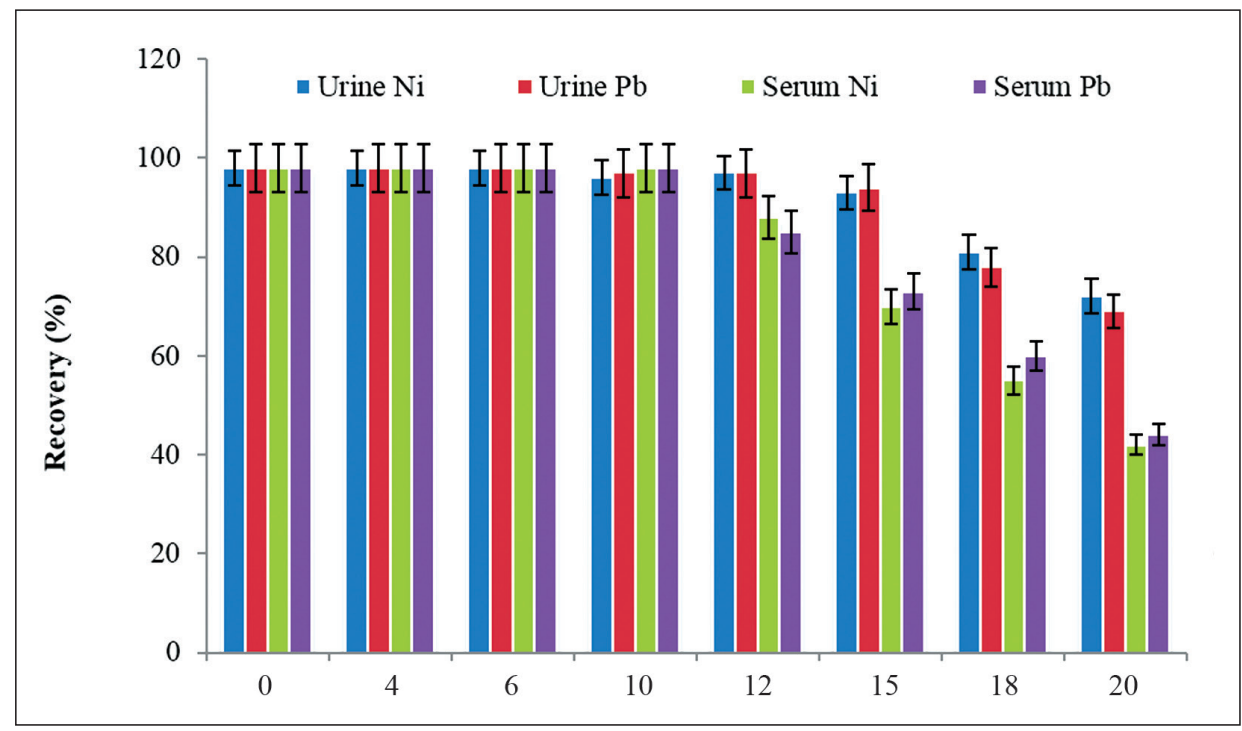

Fig. 8. The effect of sample volume on lead and nickel extraction in urine and blood samples by the DIL- $\mu$-SPE procedure

Table 3. The effect of interference ions on $\mathrm{Pb}(\mathrm{II})$ and $\mathrm{Ni}$ (II) extraction in human urine and serum samples by the DIL- $\mu$-SPE procedure

\begin{tabular}{|c|c|c|c|c|}
\hline \multirow{2}{*}{ Interfering Ions(CA) } & \multicolumn{2}{|c|}{$\begin{array}{l}\text { Mean ratio } \\
\left(\mathrm{CA} / \mathrm{C}_{\mathrm{Pb}(\mathrm{II})} ; \text { or } \mathrm{CA} / \mathrm{C}_{\mathrm{Ni}(\mathrm{II})}\right)\end{array}$} & \multicolumn{2}{|c|}{ Recovery (\%) } \\
\hline & $\mathrm{Pb}(\mathrm{II})$ & $\mathrm{Ni}(\mathrm{II})$ & $\mathrm{Pb}(\mathrm{II})$ & $\mathrm{Ni}(\mathrm{II})$ \\
\hline $\mathrm{Cr}^{3+}, \mathrm{As}^{3+}$ & 900 & 800 & 98.8 & 97.4 \\
\hline $\mathrm{Zn}^{2+}, \mathrm{Cu}^{2+}$ & 750 & 600 & 97.2 & 98.5 \\
\hline $\mathrm{Cd}^{2+}$ & 700 & 300 & 97.0 & 95.8 \\
\hline $\mathrm{I}^{-}, \mathrm{Br}^{-}, \mathrm{F}^{-}, \mathrm{Cl}^{-}$ & 1200 & 1100 & 99.2 & 98.6 \\
\hline $\mathrm{Al}^{3+}, \mathrm{V}^{3+}$ & 650 & 700 & 98.0 & 96.9 \\
\hline $\mathrm{Na}^{+}, \mathrm{K}^{+}, \mathrm{Cl}^{-}, \mathrm{Ca}^{2+}, \mathrm{Mg}^{2+}$ & 900 & 800 & 97.5 & 97.1 \\
\hline $\mathrm{Co}^{2+}, \mathrm{Mn}^{2+}$ & 600 & 800 & 99.1 & 97.7 \\
\hline $\mathrm{Hg}^{2+}$ & 50 & 80 & 96.6 & 97.3 \\
\hline $\mathrm{Ag}^{+}$ & 200 & 150 & 98.0 & 98.7 \\
\hline $\mathrm{SCN}^{-}, \mathrm{S}_{2} \mathrm{O}_{3}^{2-}, \mathrm{CH}_{3} \mathrm{COO}^{-}, \mathrm{NO}_{3}^{-}$ & 800 & 900 & 97.6 & 99.4 \\
\hline
\end{tabular}

extraction for $\mathrm{Pb}(\mathrm{II})$ and $\mathrm{Ni}(\mathrm{II})$ in present of the interference ions. Therefore, the IL-MWCNTs can be used as a favorite adsorbent for $\mathrm{Pb}$ (II) and $\mathrm{Ni}$ (II) extraction in urine and serum samples.

\subsection{Real sample analysis}

The $\mathrm{Pb}(\mathrm{II})$ and $\mathrm{Ni}(\mathrm{II})$ ions was determined in urine and serum samples based on IL-MWCNTs by the DIL- $\mu$-SPE procedure coupled to ETAAS. By optimizing parameters, the means of 10 times determinations, for $\mathrm{Pb}(\mathrm{II})$ and $\mathrm{Ni}(\mathrm{II})$ ions were calculated. The human urine and serum samples were spiked with $\mathrm{Pb}(\mathrm{II})$ and $\mathrm{Ni}(\mathrm{II})$ standard solutions for $0.4-30 \mu \mathrm{g} \mathrm{L}^{-1}$ and $0.2-5.8$ $\mu \mathrm{g} \mathrm{\textrm {L } ^ { - 1 }}$ at $\mathrm{pH}=8$, respectively (Table 4 and 5 ). The results showed us, the spiking real samples 
has favorite accuracy and pricision for lead and nickel analysis in difficulty matrixes. The mean extraction efficiency of spiked urine and serum samples for $\mathrm{Pb}(\mathrm{II})$ and $\mathrm{Ni}(\mathrm{II})$ ions were obtained from $95.2 \%$ to $104.3 \%$ ( $\mathrm{RSD} \%<5 \%$ ) for ten samples. The spike samples demonstrated that the proposed method have satisfactory results for extraction and determination $\mathrm{Pb}(\mathrm{II})$ and $\mathrm{Ni}(\mathrm{II})$ ions in human biological samples. In addition, the $\mathrm{Pb}(\mathrm{II})$ and $\mathrm{Ni}(\mathrm{II})$ ions concentration in urine and serum samples was mesured with ICP-MS and compared to DIL- $\mu$-SPE/ET-AAS procedure

Table 4. Validation of lead determination $(\mathrm{Pb})$ based on spiking of human serum, blood, plasma and urine samples by DIL- $\mu$-SPE procedure

\begin{tabular}{llll}
\hline Human Sample* & Spike $\left(\mu \mathrm{g} \mathrm{L}^{-1}\right)$ & "Found $\left(\mu \mathrm{g} \mathrm{\mathbf {L } ^ { - 1 }}\right)$ & Recovery $(\%)$ \\
\hline \multirow{2}{*}{ Blood } & --- & $14.7 \pm 0.6$ & --- \\
\hline \multirow{2}{*}{ Serum } & 15 & $29.8 \pm 1.3$ & 100.6 \\
\hline \multirow{2}{*}{ Urine } & --- & $15.2 \pm 0.7$ & -- \\
& 15 & $30.1 \pm 1.4$ & 99.3 \\
\hline \multirow{2}{*}{ Plasma } & --- & $8.4 \pm 0.3$ & 98.0 \\
\hline
\end{tabular}

*Mean of three determinations of samples \pm confidence interval $(\mathrm{P}=0.95, \mathrm{n}=10)$

All samples volumes diluted with DW (1:10), Dilution factor $=10$

Table 5. Validation of nickel determination (Ni) based on spiking of human serum, blood, plasma and urine samples by DIL- $\mu$-SPE procedure

\begin{tabular}{lccc}
\hline \multirow{2}{*}{ Human Sample* } & Spike $\left(\mu \mathbf{~ L}^{-1}\right)$ & *Found $\left(\boldsymbol{\mu g} \mathbf{L}^{-1}\right)$ & Recovery $(\%)$ \\
\hline \multirow{2}{*}{ Blood } & --- & $2.22 \pm 0.12$ & --- \\
& 2.5 & $4.63 \pm 0.18$ & 96.4 \\
\hline \multirow{2}{*}{ Serum } & --- & $2.65 \pm 0.11$ & --- \\
& 2.5 & $5.27 \pm 0.28$ & 104.8 \\
\hline \multirow{2}{*}{ Urine } & --- & $1.35 \pm 0.06$ & 99.3 \\
\hline \multirow{2}{*}{ Plasma } & 1.5 & $2.84 \pm 0.12$ & --- \\
\hline
\end{tabular}

*Mean of three determinations of samples \pm confidence interval $(\mathrm{P}=0.95, \mathrm{n}=10)$

Table 6. Comparing of DIL- $\mu$-SPE /ET-FAAS with ICP-MS method for mean concentration of $\mathrm{Pb}$ and $\mathrm{Ni}$ in human samples $\left(\boldsymbol{\mu g} \mathrm{L}^{-1}\right)$

\begin{tabular}{llllll}
\hline \multirow{2}{*}{ Sample } & ICP-MS & ICP-MS & & $\begin{array}{l}\text { *IL-MWCNTs } \\
\text { /ET-AAS }\end{array}$ & $\begin{array}{l}\text { *IL-MWCNTs /ET- } \\
\text { AAS }\end{array}$ \\
\cline { 2 - 3 } \cline { 6 - 7 } & $\mathrm{Pb}$ & $\mathrm{Ni}$ & & $\mathrm{Pb}$ & $\mathrm{Ni}$ \\
\hline Blood & $29.56 \pm 0.96$ & $2.53 \pm 0.04$ & & $28.82 \pm 1.42$ & $2.41 \pm 0.11$ \\
\hline Urine & $18.13 \pm 0.35$ & $1.87 \pm 0.03$ & & $17.49 \pm 0.77$ & $1.95 \pm 0.09$ \\
\hline Serum & $27.48 \pm 0.81$ & $4.68 \pm 0.08$ & & $27.06 \pm 1.32$ & $4.43 \pm 0.23$ \\
\hline
\end{tabular}

*Mean of three determinations of samples \pm confidence interval $(\mathrm{P}=0.95, \mathrm{~N}=10)$,

The lead samples diluted with DW (1:10) 
(Table 6). The precision and accuracy of results showed the validation of methodology for the $\mathrm{Pb}$ (II)/ Ni(II) determination by IL-MWCNTs adsorbent.

\section{Conclusions}

A simple and efficient method based on ILMWCNTs adsorbent was used for separation and determination of nickel and lead in urine and serum samples by ET-AAS. By the DIL- $\mu$-SPE procedure, high recovery and efficient extraction was obtained at optimized conditions. The linear range and working range for $\mathrm{Ni}(\mathrm{II})$ and $\mathrm{Pb}$ (II) was achieved 0.2-3.42 $\mu \mathrm{g} \mathrm{L}^{-1} / 0.4-17.6 \mu \mathrm{g} \mathrm{L}^{-1}$ and $0.2-5.8 \mu \mathrm{gL}^{-1} / 0.4-$ $30 \mu \mathrm{g} \mathrm{L}^{-1}$ for $10 \mathrm{~mL}$ of urine and serum samples, respectively. The mean correlation coefficient and enrichment factor for $\mathrm{Ni}$ (II) and $\mathrm{Pb}$ (II) were obtained 0.9997/0.9995 and 24.7/5.1, respectively. The $\mathrm{NH}_{2}$ group in IL-MWCNTs was coordinated with $\mathrm{Ni}(\mathrm{II})$ and $\mathrm{Pb}$ (II) cations and separated from liquid phase by centrifuging process. The high adsorption capacities, recovery, enrichment and favorite reusability caused to consider the DIL- $\mu$ SPE procedure as a new methodology for nickel and lead extraction in human samples with low LOD and RSD ( $>5 \%)$ in optimized conditions. The validation methodology based on spiking samples and ICP-MS analysis showed, the DIL- $\mu$-SPE method can be used as applied techniques for Ni(II) and $\mathrm{Pb}(\mathrm{II})$ determination in human samples.

\section{Acknowledgements}

The authors wish to thank Semnan University Research Council, Semnan, Iran.

\section{References}

[1] World Health Organization (WHO), Preventing disease through healthy environments: exposure to lead: a major public health concern, 2019.

[2] Environmental Protection Agency (USEPA) Basic Information About Lead in Drinking Water, 2014.

[3] Agency for Toxic Substances and Disease Registry, Division of Toxicology and Human
Health Sciences, 1600 Clifton Road NE, Mailstop S102-1, Atlanta, GA 30333, revision 2019.

[4] Agency for Toxic Substances and Disease Registry (ATSDR), Toxicological profile for Lead,Atlanta, GA: U.S. Department of Health and Human Services, Public Health Service, 2019.

[5] Agency for Toxic Substances and Disease Registry (ATSDR), Toxicological profile for Nickel. Atlanta, GA: U.S. Department of Health and Human Services, Public Health Service, 2005.

[6] A.A. Ab Latif Wani, J.A. Usmani, Lead toxicity: a review, Interdiscip. toxicol., 8 (2015) 55-64.

[7] G. Flora, D. Gupta, A. Tiwari, Toxicity of lead: a review with recent updates, Interdiscip. toxicol., 5 (2012) 47-58.

[8] T. Dignam, R. B. Kaufmann, L. LeStourgeon, M. Jean Brown, Control of lead sources in the United States, public health progress and current challenges to eliminating lead exposure, J. Public Health Manag. Pract., (2019) S13-S22. PMC6522252, https://doi. org/10.1097/PHH.0000000000000889.

[9] M. Kirberger, J.J. Yang, Structural differences between $\mathrm{Pb}^{2+}$ and $\mathrm{Ca}^{2+}$ binding sites in proteins: implications with respect to toxicity, J. Inorg. Biochem., 102 (2008) 1901-1909.

[10] J.S. Magyar, T.-C. Weng, C.M. Stern, D.F. Dye, B.W. Rous, J.C. Payne, B.M. Bridgewater, A. Mijovilovich, G. Parkin, J.M. Zaleski, Reexamination of lead (II) coordination preferences in sulfur-rich sites: implications for a critical mechanism of lead poisoning, J. Am. Chem. Soc., 127 (2005) 9495-9505.

[11] United States Food and Drug Administration (USFDA), Elemental impurities guidance for industry, Department of Health and Human Services, p. 41, 2017.

[12] B.C. Schwarcz, L. Chilton, B. Shirley, S. Seifert, Childhood lead exposure associated with the use of kajal, an eye cosmetic from Afghanistan Albuquerque, New Mexico, 
Morb. Mortal Wkly. Rep., 62 (2013) 917-919.

[13] K.L. Caldwell, P.Y. Cheng, J.M. Jarrett, Measurement challenges at low blood lead levels, Pediatrics., 140 (2017) e20170272. https://doi.org/10.1542/peds.2017-0272

[14] D.C. Bellinger, Neurological and behavioral consequences of childhood lead exposure. PLOS Med., 5 (2008) e115. https://doi. org/10.1371/journal.pmed.0050115.pdf.

[15] A. Abbas, A.M. Al-Amer, T. Laoui, M.J. AlMarri, M.S. Nasser, M. Khraisheh, Heavy metal removal from aqueous solution by advanced carbon nanotubes: critical review of adsorption applications, Sep. Purifi. Technol., 157 (2016) 141-61.

[16] S. Feng, X. Wang, G. Wei, P. Peng, Y. Yang, Z. Cao, Leachates of municipal solid waste incineration bottom ash from Macao: Heavy metal concentrations and genotoxicity, Chemosphere., 67 (2007) 1133-1137.

[17] S.K. Seilkop, A.R. Oller, Respiratory cancer risks associated with low-level nickel exposure: An integrated assessment based on animal, epidemiological, and mechanistic data, Regul. Toxicol. Pharm., 37 (2003) 173190.

[18] Agency for Toxic Substances and Disease Registry, Division of Toxicology and Human Health Sciences, 1600 Clifton Road NE, Mailstop S102-1, Atlanta, GA 30333, revision 2019.

[19] Agency for Toxic Substances and Disease Registry (ATSDR), Toxicological profile for Nickel. Atlanta, GA: U.S. Department of Health and Human Services, Public Health Service, 2005.

[20] A. Fadhil Khudhair, M. Khudhair Hassan, H. F. Alesary , A. S. Abbas, Simple preconcentration method for the determination of nickel(II) in urine samples using UVVIS spectrophotometry and flame atomic absorption spectrometry techniques, Indones. J. Chem., 19 (2019) 638 - 649.
[21] S. Orecchio, D. Amorello, Determination of trace elements in gluten-free food for celiac people by ICP-MS, Microchem. J., 116 (2014) 163-172.

[22] M. Arjomandi, H. Shirkhanloo, A review: Analytical methods for heavy metals determination in environment and human samples, Anal. Methods Environ. Chem. J., 2 (2019) 97-126.

[23] J. Shan Qun, W. Xiang Yu, S. Jin Lyu, Analysis of nickel distribution by synchrotron radiation $\mathrm{X}$-ray fluorescence in nickel-induced earlyand late-phase allergic contact dermatitis in Hartley guinea pigs, Chinese Med. J., 132 (2019) 1959-1964.

[24] A. Baysal, S. Akman, A rapid solid sampling method for determination of nickel and copper along human hair by ETAAS, Microchem. J., 98 ( 2011) 291-296

[25] M. Eftekhari, M. Gheibi, M. Akrami, F. Iranzad, Solid-phase extraction of ultratrace levels of lead using tannic acid-coated graphene oxide as an efficient adsorbent followed by electrothermal atomic absorption spectrometry; response surface methodologycentral composite design, New J. Chem., 42 (2018) 1159-1168.

[26] M. Rajabi M. Abolhosseini, Magnetic dispersive micro-solid phase extraction merged with micro-sampling flame atomic absorption spectrometry using (Zn-Al $\mathrm{LDH})-(\mathrm{PTh} / \mathrm{DBSNa})-\mathrm{Fe}_{3} \mathrm{O}_{4}$ nanosorbent for effective trace determination of nickel(II) and cadmium(II) in food samples, Microchem. J., 159 (2020) 105450.

[27] S. Azimi, Z. Es'haghi, A magnetized nanoparticle based solid-phase extraction procedure followed by inductively coupled plasma atomic emission spectrometry to determine arsenic, lead and cadmium in water, milk, Indian rice and red tea, Bull. Environ. Contam. Toxicol., 98 (2017) 830-836.

[28] W. Ding, X. Wang, T. Liu., Preconcentration/ extraction of trace bisphenols in milks using a novel effervescent reaction-assisted 
dispersive solid-phase extraction based on magnetic nickel-based $\mathrm{N}$-doped graphene tubes, Microchem. J., 150 (2019) 104109.

[29] M. Shirani, F. Salari, S. Habibollahi, A. Akbari, Needle hub in-syringe solid phase extraction based a novel functionalized biopolyamide for simultaneous green separation/ preconcentration and determination of cobalt, nickel, and chromium (III) in food and environmental samples with micro sampling flame atomic absorption spectrometry, Microchem. J., 152 (2020) 104340.

[30] S. M. Sorouraddin, M. A. Farajzadeh H. Nasiri, Picoline based-homogeneous liquidliquid microextraction of cobalt(II) and nickel(II) at trace levels from a high volume of an aqueous sample, Anal. Methods, 11 (2019) 1379-1386.

[31] L. Khoshmaram, Air-assisted liquid-liquid microextraction combined with flame atomic absorption spectrometry for determination of trace $\mathrm{Pb}$ in biological and aqueous samples, Int. J. Environ. Anal. Chem., 101 (2021) 838848.

[32] H. Shirkhanloo, S. Davari Ahranjani, A lead analysis based on amine functionalized bimodal mesoporous silica nanoparticles in human biological samples by ultrasound assisted-ionic liquid trap-micro solid phase extraction, J. Pharm. Biomed. Aanl., 157 (2018) 1-9.

[33] H. Shirkhanloo, Z. Karamzadeh, A novel biostructure sorbent based onCysSB/MetSB@ MWCNTs for separation of nickel and cobalt in biological samples by ultrasound assisteddispersive ionic liquid-suspension solid phase micro extraction, J. Pharm. Biomed. Anal., 172 (2019) 285-294.

[34] N. Esmaeili, J. Rakhtshah, E. Kolvari, H. Shirkhanloo, Ultrasound assisted-dispersivemodification solid-phase extraction using task-specific ionic liquid immobilized on multiwall carbon nanotubes for speciation and determinationmercury in water samples, Microchem. J., 154 (2020) 104632. 